\title{
Synthesis and Physical Properties of Decylbithiophene End-Capped Oligomers Based on Naphthalene, Anthracene and Benzo[1,2-b:4,5-b']dithiophene
}

\author{
Sang Hun Jang, Tnıong Ba Tai, Min Kyu Kim, Jeong Woo Han, Yun-Hi Kim, \\ Sung Chul Shin, ${ }^{\dagger}$ Yong Jin Yoon, ${ }^{\dagger}$ Soon Ki Kwon, ${ }^{\ddagger-}$ and Sang-Gyeong Lee ${ }^{-}$ \\ Department of Chemistry and Research Institute of Life Science, Graduate School for Holecular Haterials and \\ Nanochemistrv, Gleongsang National Lniversity, Jinju 660-701. Korea. * E-mail: leesangiàgnuac.kr \\ ${ }^{\dagger}$ Department of Chemistrv, Research Institute of Natural Science. Graduate School for Molecular Materials and \\ Nanochemistrv, Gveongsang National Lniversin. Jinju 660-701, Korea \\ ${ }_{4}$ School of Wano \& Advanced Materials and Enginnering, Gyeongsang National Lninersity, Jinju 660-701, Korea \\ Received September 18, 2008, Accepted February 2, 2009
}

\begin{abstract}
The new candidates for OTFTs, which were composed of naphthalene, anthracene, benzo[ $\left.1,2-b: 4,5-b^{\circ}\right]$ dithiophene and 2-decylbithiophene end-capper were synthesized under Suzuki coupling reaction conditions. All of the oligomers were characterized by FT-IR, mass analysis, UV-vis, PL spectrum, cyclic voltametry (CV), differential scanning calorimetry (DSC), thermal gravimetric analysis (TGA), ${ }^{1} \mathrm{H}-\mathrm{NMR}$ and ${ }^{13} \mathrm{C}-\mathrm{NMR}$. Investigation of physical properties showed that all of the oligomers have higher oxidation potential and good thermal stability. Especially, DBT-DtB-DBT is soluble in conmon solvents and suitable for low cost processing technologies.
\end{abstract}

Key Words: Suzuki coupling. Photoluminescence, Cyclic voltanetry, Thermal gravinetric analysis, Differential scanning calorimetry

\section{Introduction}

During the past decades. organic semiconducting materials have been interest of electronic industry due to their high potential applications as a low-cost alternative to silicon. A many kinds of conjugated oligomers and polymers were synthesized and investigated for their electrochemical property as new organic semiconductor candidates. ${ }^{1-5}$ Among the most potential materials for organic semiconductor. thiophene and anthracene based oligomers have received special attentions due to their good electrochemical properties and themmal properties. ${ }^{6-9}$ Recently. hybrid thiophene-phenylene oligomers were reported as good organic materials for OTFTs (organic thin film transistors). ${ }^{1612}$ Ponomarenko and co-worker also reported the synthesis and characterization of the bithiophenephenylene-bithiophene conjugated cores. which have good oxidation and themmal stability as well as good characterizations for OTFTs. ${ }^{13.14}$ As an example, the mobility of 1.4-bis(5-decyl2.2-bithien-5-yl)benzene (Dec-2T-Ph-2T-Dec) is up to 0.3 $\mathrm{cm}^{2} /$ V.s. This result was explained due to the effect of the long decyl end group. which is leading improved molecular order. More recently, it was also reported that semiconducting materials based on naphthalene and anthracene core units exhibited excellent field effect performances with mobility as high as $0.1+\mathrm{cm}^{2} /$ Vs and on/off ratio up to $6.3 \times 10^{6}$. $^{5}$

In this paper. we report the synthesis of a new candidates for OTFTs. which were composed of core units such as naphthalene, anthracene and benzo[1.2-b:4,5-b']dithiophene and 2-decylbithiophene as an end-capper. And also we report the electrochemical properties of sytnthesized molecules.

\section{Results and Discussion}

Synthesis. The synthetic strategy to the desired molecules is illustrated in Scheme 1. 2 and 3. Compound + was prepared from bithiophene 1 as starting material (Scheme 1). A starting material bithiophene 1 was prepared according to literature ${ }^{16}$ and easily converted into 2-decylbithiophene 2 . which was brominated with NBS in DMF to give 3 in $94 \%$ yield. Compound 3 was treated with 2 -isopropoxy-4.4,5,5-tetramethyl1,3.2-dioxaborolane in the presence of $n-\mathrm{BuLi}$ to give 4 in $73 \%$ yield.

The preparation of 2.6-dibromobenzo[1,2-b:4.5-b']dithiophene $11^{17}$ and 2.9 -dibromoanthracene $14^{18}$ were synthesized according to literature procedures. respectively (Scheme 2). The 2,6-dibromonaphthalene $\mathbf{1 5}$ was purchased from Alfa Aesar Co.
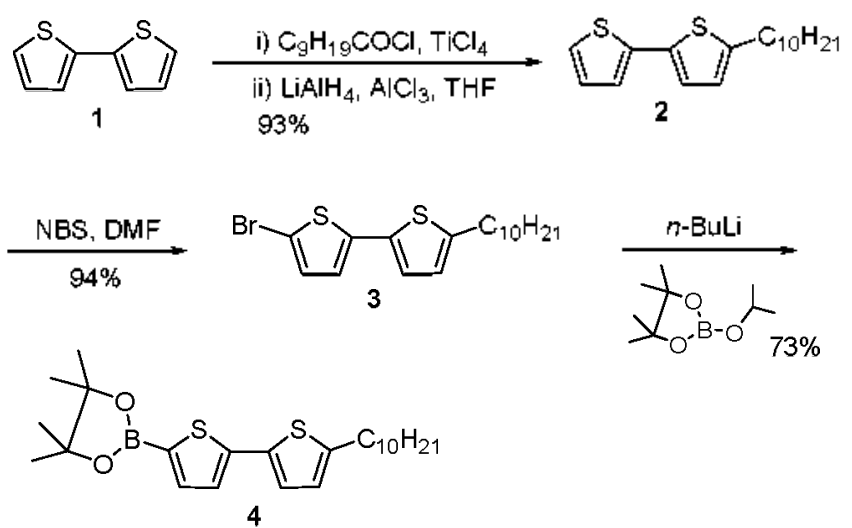

Scheme 1 
<smiles>Brc1ccsc1</smiles><smiles>N#CO[W]=O</smiles>

5<smiles>O=Cc1sccc1Br</smiles>
6<smiles>OC(c1ccsc1)c1sccc1Br</smiles><smiles>Brc1ccsc1Cc1ccsc1</smiles>

8

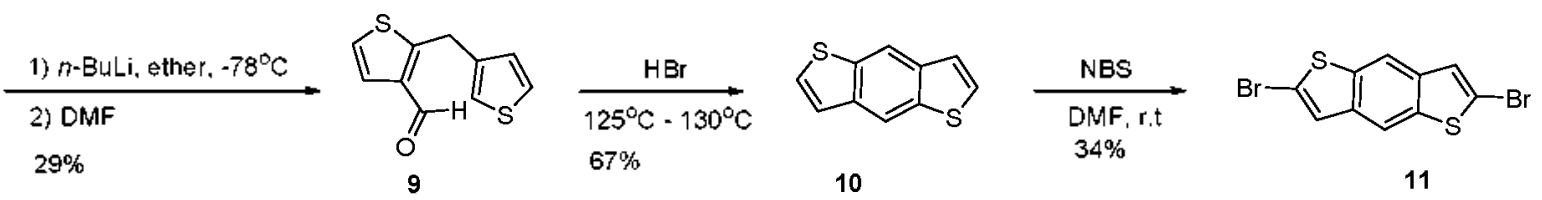

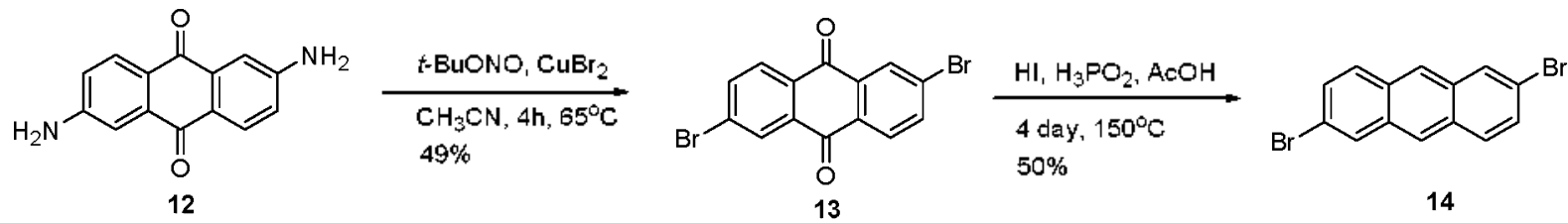

Scheme 2

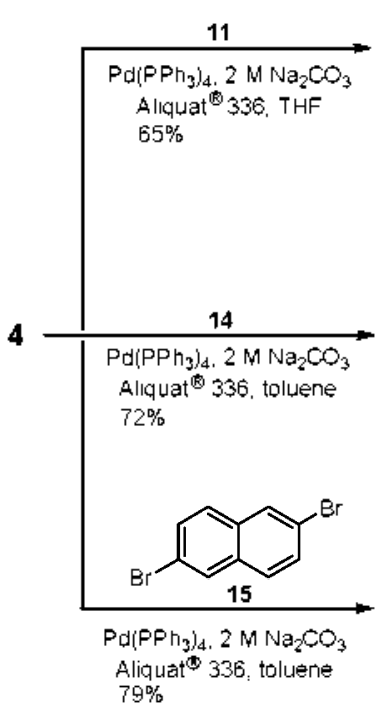

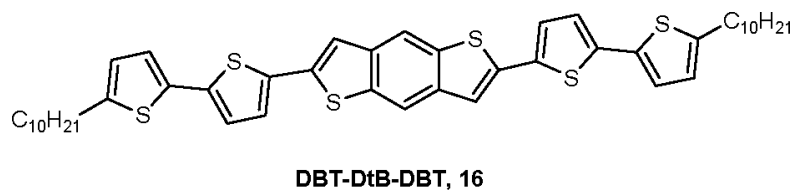

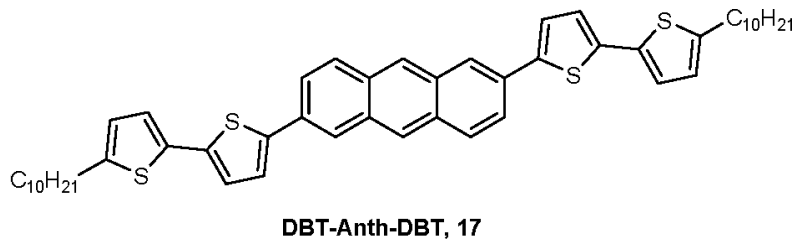

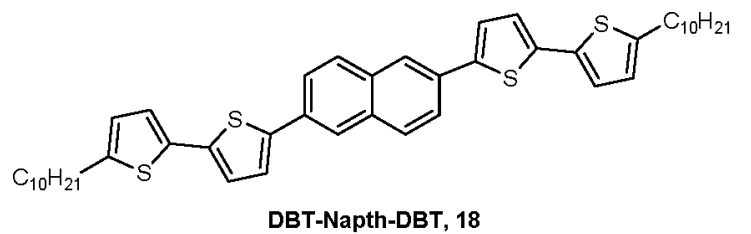

Scheme 3
The obtained 4 was used for coupling reaction with 11 . 14 and 15 in next step. The target material DBT-DtB-DBT (16). DBT-Anth-DBT (17) and DBT-Napth-DBT (18) were synthesized under the conditions of Suzuki coupling reaction in the presence of Aliquat ${ }^{B} 336$ as a phase transfer catalyst in toluene to give $65 \% .72 \%$ and $79 \%$ yield, respectively. The coupling reaction between 4 and 14 or 15 were carried out in toluene as an usual solvent of Suzuki reaction conditions to give 17 and 18 easily. However, the coupling reaction between 4 and 11 were carried out in THF instead of toluene (Scheme 3).

Compound 16 was soluble in common solvents and the structure was confirmed by ${ }^{1} \mathrm{H}-\mathrm{NMR} .{ }^{13} \mathrm{C}-\mathrm{NMR}, \mathbb{R}$ and mass analysis. However, compound 17 and 18 were soluble in hot toluene. chlorobenzene and dichlorobenzene only. Therefore. their stnictures were confirmed by mass and IR spectroscopy because of their poor solubility.

Optical and electrochemical properties. The optical properties of synthesized oligomers were investigated using
UV-vis absorption and photoluminescence (PL) in dilute $\mathrm{CHCl}_{\hat{s}}$ solution and on thin film. The results are shown in Figure 1 and 2 and summarized in Table 1 . UV absorption maxina in dilute $\mathrm{CHCl}_{3}$ solution were exhibited at $346 \mathrm{~nm}$ for 16. at 310 and $404 \mathrm{~nm}$ for 18 and at $361,430.452 \mathrm{~nm}$ for 17. respectively. The experimental results of UV absorption of $\mathbf{1 6}$, 17 and 18 were almost coincident with the increasing of conjugation length in their structures. In PL spectra, all of the oligoners exhibited blue fluorescence in solution. The enussion spectra of oligomers in solid state displayed a large red slift about $60-80 \mathrm{~lm}$. These results can be originated from the formation of aggregation or excimer in thin film due to $\pi-\pi^{*}$ stacking or internolecular interaction caused by their planar structures. The electrochemical behaviors of oligomers were investigated by cyclic voltametry (CV). The crclic voltammograms (CVs) of oligomers were recorded in a $1.0 \times 10^{-3} \mathrm{M}$ $\mathrm{CHCl}_{3}$ solution containing $0.1 \mathrm{M} \mathrm{Bu}_{4} \mathrm{NClO}_{4}$. The oxidation peak potentials of oligomers were summarized in Table 1 . In 


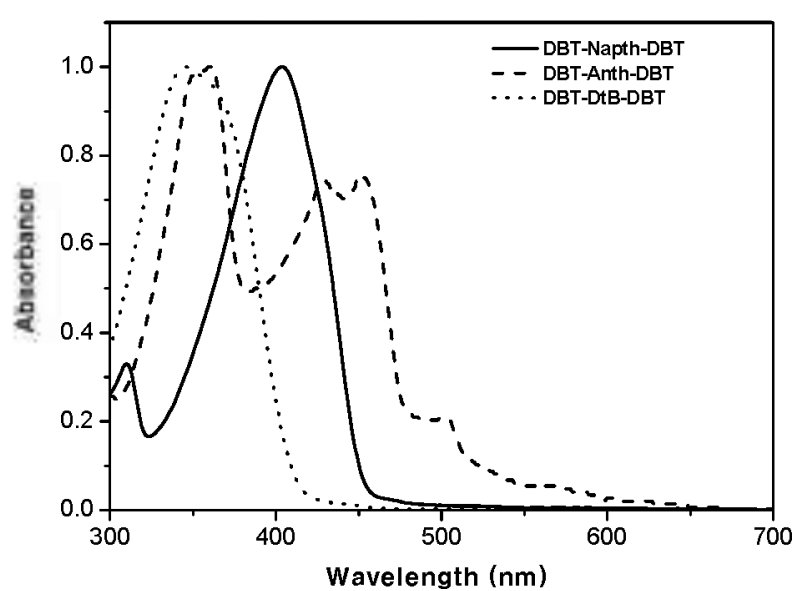

Figure 1. UV-vis spectra of DBT-DtB-DBT, DBT-Anth-DBT and DBT-Napth-DBT in dilute $\mathrm{CHCl}_{3}$ solution.

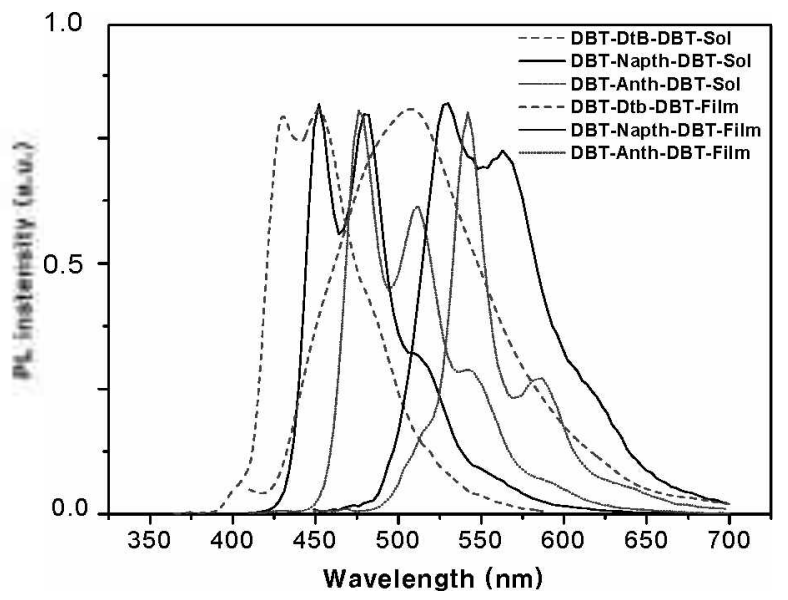

Figure 2. PL spectra of DBT-DtB-DBT, DBT-Anth-DBT and DBTNapth-DBT in dilute $\mathrm{CHCl}_{s}$ solution and solid state.

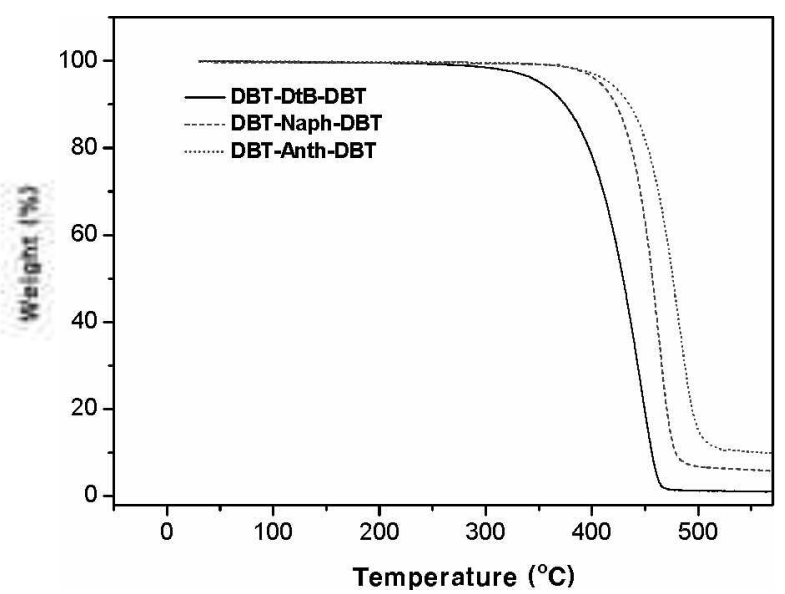

Figure 3. TGA curves of DBT-DtB-DBT, DBT-Anth-DBT and DPT-Napth-DRT.

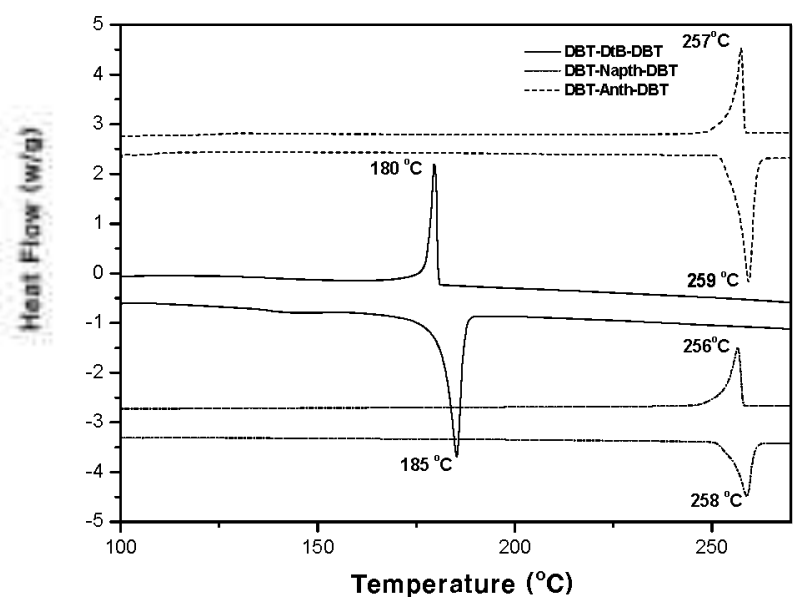

Figure 4 . DSC themograms of DBT-DtB-DBT, DBT-Anth-DBT and DBT-Napth-DBT.

Table 1. Summary of the physical data of DBT-DtB-DBT, DBT-Anth-DBT and DBT-Napth-DBT.

\begin{tabular}{|c|c|c|c|c|c|c|c|c|}
\hline \multirow{2}{*}{ Compound } & \multirow{2}{*}{$\lambda_{\mathrm{abb}: \mathrm{nm}}{ }^{\prime \prime}$} & \multicolumn{2}{|c|}{$\lambda_{\text {em }: \pi m}{ }^{b}$} & \multirow{2}{*}{$E_{\mathrm{w}} / \mathrm{eV}$} & \multirow{2}{*}{$\mathrm{T}_{s \mathrm{~d}} / \mathrm{C}^{\mathrm{c}}$} & \multirow{2}{*}{$E_{\mathrm{g}} / \mathrm{eV}$} & \multirow{2}{*}{$\mathrm{HOMO/eV}$} & \multirow{2}{*}{$\mathrm{LUMO} / \mathrm{eV}^{e}$} \\
\hline & & Solution & Film & & & & & \\
\hline DBT-DtB-DBT & 346 & 431,452 & 509 & 1.0 & 351 & 3.00 & -5.4 & -2.40 \\
\hline DBT-Anth-DBT & $361,430,452$ & 476,512 & 542,587 & 0.89 & 412 & 2.55 & -5.3 & -2.75 \\
\hline DBT-Napth-DBT & 310,404 & 479,452 & 530,563 & 1.1 & 406 & 2.74 & -5.4 & -2.66 \\
\hline
\end{tabular}

"Measured in dilute $\mathrm{CHCl}_{3}$ solution "Excited at the absorption maxima "Obtained from DSC and TGA measurements under $\mathrm{N}_{2}$ at a heating rate of 10 ${ }^{\circ} \mathrm{C}$ min ${ }^{d}$ Calculated using the empirical equation: $\mathrm{HOMO}=-\left(4.44-E_{\text {ms:et }}\right){ }^{\circ} \mathrm{Calculated}$ from LUMO $=\mathrm{HOMO}+E_{\mathrm{g}}$

addition the optical band gaps $\left(E_{g}\right)$ of oligomers were determined from the absorption onset. The optical band gaps of 16. 17 and 18 were found to be 3.00, 2.55 and 2.74 . respectively. Table 1 summarizes the HOMO/LUMO energies of DBT-DtB-DBT. DBT-Anth-DBT and DBT-Napth-DBT estimated from the relation $E_{(\mathrm{LLM})}=E_{\text {(HOML) }}+E_{\text {gap. }}$. where

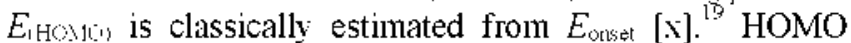
energy level of the oligomers were shown in the range of -5.3 $\mathrm{eV}$ to $-5.4 \mathrm{eV}$. which are lower than that of $\alpha$-sexithiophene ( $\alpha$ 6T. HOMO level of $-5.0 \mathrm{eV}){ }^{2(1}$ These results indicated that the synthesized oligomers have low band gap. For p-type semi conductors. the majority carriers are holes. For this reason it is important to reduce the energy barrier between gold electrode and organic semiconductor so that the HOMO levels of p-type semiconductors should be closed to the work function of gold electrode $(-5 .+\mathrm{eV})^{\hat{2}}$ Therefore. it can be assumed that the injection of charge carriers may be hindered. In addition. the determined HOMO levels of p-type seniconductors match well to the work function of gold metal used in OTFTs. which leads increasing of efficiency of the injection and transport of holes.

Themal properties. The thermal properties of obtained 
oligomers were investigated by thermal gravimetric analysis (TGA) and differential scanning calorimetry (DSC) in a nitrogen atmosphere. TGA curve reveals that the oligomers have high thermal stability. Five percent weight loss $\left(\mathrm{T}_{\text {sil }}\right)$ was observed at $35 \mathrm{I}^{\circ} \mathrm{C}, 412^{\circ} \mathrm{C}$ and $406^{\circ} \mathrm{C}$ for 16,17 and 18. respectively. The results are shown in Figure 3 and summarized in Table 1

These decomposition temperatures are higher than that of $\boldsymbol{a}$ $6 \mathrm{~T}\left(\mathrm{~T}_{\mathrm{sil}}=322^{\circ} \mathrm{C}\right)$ under similar conditions. ${ }^{\text {ll }}$ The decomposition of 16 is lower than those of $\mathbf{1 7}$ and $\mathbf{1 8}$, this result can be explained due to less thermal stability of benzo[1,2-b:4,5-b']dithiophene. The thermal characterization of 16.17 and 18 were investigated by DSC themogram. Compound 16 exhibits an endothermic peak at $185^{\circ} \mathrm{C}$ and an exothermic transition at $180^{\circ} \mathrm{C}$. The results are summarized in Table 1. DSC thermogram of 17 reveals an endothermic peak at $259^{\circ} \mathrm{C}$ and an exothermic peak at $257^{\circ} \mathrm{C}$. Compound 17 also displayed good thermal feature under heating and cooling cycle. DSC thermogram of 18 reveals an endothermic peak at $316^{\circ} \mathrm{C}$ and an exothemic peak was observed at $309^{\circ} \mathrm{C}$. All revealed thermal features of 16,17 and 18 showed that all of the three oligomers are cry stalline and it is expected that their thin films are well ordered under heat treatment.

\section{Conclusions}

We reported the synthesis of new 2-decylbithiophene endcapped oligomers, which were synthesized from Suzuki coupling reaction of naphthalene, anthracene and benzo[1.2-b: $\left.4.5-b^{\prime}\right]-$ dithiophene with compound $\mathcal{4}$ and their properties were investigated. Investigation of thermal properties revealed that all of the oligomers have good thermal stability from $350^{\circ} \mathrm{C}$ to $410^{\circ} \mathrm{C}$ as compared to $06 \mathrm{~T}\left(\mathrm{~T}_{\mathrm{sil}}=322^{\circ} \mathrm{C}\right.$ ). The optical and electrochemical properties showed that the synthesized oligomers have higher oxidation potential due to their high HOMO energy levels ( $-5.4 \mathrm{eV}$ for $\mathbf{1 6},-5.4 \mathrm{eV}$ for 18 and -5.3 $\mathrm{eV}$ for 17). In particularly. compound 16 exhibited good solubility in common solvents and can be used in low cost fabrication technologies. The fabrication of OTFTs using performance will be reported in the future.

\section{Experimental}

Materials. 2-Bromothiophene, 3-bromothiophene. 2.6-diaminoanthraquinone decanoyl chloride. N-bromosuccinimide (NBS) 2-isopropoxy-4.4.5.5-tetramethyyl-1.3.2-dioxaborolane. $N$-formylpiperidine, $N, N$-dimethylformamide (DMF). copper (II) bromide tetrakis(triphenylphosphine)palladium. Aliquat ${ }^{\mathrm{B}}$ 336 were purchased from Aldrich Chemical Co. The 2.6dibromonaphthalene (15) was purchased from Alfa Aesar Co. All reagents purchased commercially were used without further purification except for diethylether. tetrahydrofuran (THF) dried with sodium/benzophenone

Synthesis of 2,2 '-bithiophene $(1),{ }^{16} 2,6$-dibnomobenzo[1,2b:4,5-b']dithiophene (11) ${ }^{1 / 2}$ and 2,9-dibromoanthracene $(14)^{18}$ were carried out according to literature procedures.

2-Decyl-5-(thiophen-2-yl)thiophene (2). To a solution of 2.2 'bithiophene 1 ( $3.17 \mathrm{~g} .19 .1 \mathrm{mmol}$ ) in anhydrous benzene
(20 $\mathrm{mL}$ ) was added decanoyl clloride $(4.07 \mathrm{~mL}, 20.0 \mathrm{mmol})$ at r.t. $\mathrm{TiCl}_{4}(2.25 \mathrm{~mL} .20 .5 \mathrm{mmol})$ was added to the reaction nuxture at $0^{\circ} \mathrm{C}$ and stirred for 15 min at $0^{\circ} \mathrm{C}$. Ice water was added to the reaction misture and the resulting mixture was diluted with $\mathrm{CH}_{2} \mathrm{Cl}_{2}(50 \mathrm{~mL})$, washed successively with water $(200 \mathrm{~mL})$ and saturated aqueous solution of $\mathrm{NaHCO}_{3}(100$ $\mathrm{mL}$ ), dried over $\mathrm{MgSO}_{4}$ and evaporated under reduced pressure to afford $5.00 \mathrm{~g}(85 \%)$ of yellow solid expected as the desired ketone intermediate. The intermediate was used for next step without purification.

To the solution of intermediate in toluene ( $40 \mathrm{~mL}$ ) was added a suspension of $\mathrm{LiAlH}_{4}(4.6 \mathrm{~g} .121 \mathrm{mmol})$ and $\mathrm{AlCl}_{3}$ $(4.03 \mathrm{~g} .30 .3 \mathrm{mmol})$ in anlyy drous $\mathrm{Et}_{2} \mathrm{O}(100 \mathrm{~mL})$ at $0^{\circ} \mathrm{C}$ under nitrogen atmosphere. The reaction mixture was stirred for $1 \mathrm{~h}$ at r.t. The reaction mixture was cooled to $0^{\circ} \mathrm{C}$, EtOAc $(20 \mathrm{~mL})$ and $6 \mathrm{M} \mathrm{HCl}(50 \mathrm{~mL})$ were added. The resulting nixture was extracted with $\mathrm{Et}_{2} \mathrm{O}(2 \times 300 \mathrm{~mL})$. washed with water $(100$ $\mathrm{mL}$ ). dried over $\mathrm{MgSO}_{4}$ and evaporated under reduced pressure. The residue was purified by flash column chromatography on silica gel (petroleun ether) to give compound $2(6.00 \mathrm{~g}, 93 \%)$ as a colorless oil. ' $\mathrm{H} \mathrm{NMR}\left(300 \mathrm{MHz}, \mathrm{CDCl}_{3}\right) \delta$ o 7.16 (dd. $J=$ $5.4 \mathrm{~Hz}, 1.3 \mathrm{~Hz}, \mathrm{lH}) .7 .09(\mathrm{dd}, J=3.5 \mathrm{~Hz}, 1.3 \mathrm{~Hz}, 1 \mathrm{H}), 6.99(\mathrm{dd}$. $J=5.4 \mathrm{~Hz} .3 .5 \mathrm{~Hz}, 1 \mathrm{H}) .6 .98(\mathrm{~d}, J=3.5 \mathrm{~Hz}, 1 \mathrm{H}) .6 .67(\mathrm{~d} . J=$ $3.5 \mathrm{~Hz}, \mathrm{lH}), 2.78(\mathrm{t}, J=7.6 \mathrm{~Hz}, 7.5 \mathrm{~Hz}, 2 \mathrm{H}), 1.67(\mathrm{~m}, 2 \mathrm{H}), 1.34$ (m. $\mathrm{l}+\mathrm{H}), 0.90$ (t. $J=7.0 \mathrm{~Hz}, 3 \mathrm{H}) ;{ }^{12} \mathrm{C} \mathrm{NMR}\left(75 \mathrm{MHz}_{,} \mathrm{CDCl}_{3}\right)$ ô $145.4,138.0 .134 .8 .127 .7,124.7,123.7 .123 .4 .123 .0,32.0$. 31.7, 30.2. 29.7. 29.6, 29.5. 29.4, 29.2. 22.8, 14.2; MS m/z $306\left(\mathrm{M}^{+}\right)$.

5-Bromo-5'-decyl-2,2'-bithiophene (3). In the absence of light. NBS ( $1.22 \mathrm{~g}, 6.86 \mathrm{~mm}$ ol) was added in one portion to a solution of compound $2(2.00 \mathrm{~g} .6 .53 \mathrm{mmol})$ in DMF ( $30 \mathrm{~mL})$ and the reaction mixture was stirred for $0.5 \mathrm{~h}$. After diluting with petroleum ether $(50 \mathrm{~mL})$, the reaction mixture was washed with saturated aqueous solution of $\mathrm{NH}_{4} \mathrm{Cl}(100 \mathrm{~mL})$. dried over $\mathrm{MgSO}_{4}$ and evaporated under reduced pressure. The residue was purified by column chromatography on silica gel (petroleum ether) to give compound $3(2.36 \mathrm{~g} .94 \%)$ as a white solid. mp $35-38{ }^{\circ} \mathrm{C}:{ }^{1} \mathrm{H}$ NMR $\left(300 \mathrm{MHz} . \mathrm{CDCl}_{3}\right) \delta 6.93$ $(\mathrm{d} . J=3.5 \mathrm{~Hz}, 1 \mathrm{H}), 6.91(\mathrm{~d}, J=3.5 \mathrm{~Hz} .1 \mathrm{H}), 6.82(\mathrm{~d}, J=3.7 \mathrm{~Hz}$, lH). $6.66(\mathrm{~d} . J=3.7 \mathrm{~Hz}, 1 \mathrm{H}), 2.78(\mathrm{t} . J=7.6 \mathrm{~Hz} .2 \mathrm{H}) .1 .67(\mathrm{~m}$, $2 \mathrm{H}) .1 .3+(\mathrm{m} . \mathrm{l}+\mathrm{H}) .0 .90(\mathrm{t} . J=6.9 \mathrm{~Hz}, 3 \mathrm{H}):{ }^{13} \mathrm{C}$ NMR $(75$ $\left.\mathrm{MHz}, \mathrm{CDCl}_{3}\right) \delta 145.8,139.7$. 133.9. 130.5. 124.8. 123.7 . $123.0 .110 .2,32.2,31.8,30.3,29.9,29.9 .29 .6,29.5,29.4$. 22.9. 14.4; $\mathrm{MS} \mathrm{m} / \mathrm{z} 384\left(\mathrm{M}^{-}\right)$.

2-\{5-(5-Decylthiophen-2-yl)thiophen-2-yl\}-4,4,5,5-tetra methyl-1,3,2-dioxahorolane (4). To a solution of 3 ( 1 g. 2.64 numol) in THF ( $30 \mathrm{~mL})$ was added $n-\mathrm{BuLi}(1.6 \mathrm{M}, 3.17$ mmol) at $-78 \mathrm{C}$ under nitrogen condition. The reaction mixture was warmed slowly to $-50^{\circ} \mathrm{C}$ during $20 \mathrm{~min}$. 2-Isopropoxy-4,4,5.5tetramethyl-1.3.2-dioxaborolane $(0.58 \mathrm{~mL}, 5.27 \mathrm{mmol})$ was added at $-50{ }^{\circ} \mathrm{C}$ and the temperature was increased slowly to r.t. The reaction mixture was stirred for $3 \mathrm{~h}$ at r.t and $2 \mathrm{~N} \mathrm{HCl}$ $(20 \mathrm{~mL})$ was added. The resulting mixture was extracted with ether $(2 \times 30 \mathrm{~mL})$, washed with water $(100 \mathrm{~mL})$. dried over $\mathrm{MgSO}_{4}$ and evaporated under reduced pressure. The obtained residue was recrystallized from hexane $(10 \mathrm{~mL})$ to give compound $4(0.85$ g. $93.6 \%)$ as a white solid. ${ }^{\mathrm{H}} \mathrm{H}$ NMR $(300$ $\left.\mathrm{MHz}, \mathrm{CDCl}_{z}\right) \delta 7.54$ (d. $\left.J=3.6 \mathrm{~Hz}, \mathrm{lH}\right) .7 .19$ (d. $J=3.6 \mathrm{~Hz}$. 
$1 \mathrm{H}) .7 .07(\mathrm{~d}, J=3.5 \mathrm{~Hz}, 1 \mathrm{H}), 6.71(\mathrm{~d}, J=3.5 \mathrm{~Hz} .1 \mathrm{H}), 2.81(\mathrm{t}$, $J=7.6 \mathrm{~Hz} .2 \mathrm{H}) .1 .70(\mathrm{~m} .2 \mathrm{H}) .1 .37(\mathrm{~m} .1+\mathrm{H}) .0 .91(\mathrm{t} . J=$ $6.6 \mathrm{~Hz}, 3 \mathrm{H}):{ }^{13} \mathrm{C} \mathrm{NMR}\left(75 \mathrm{MHz}, \mathrm{CDCl}_{3}\right)$ ò $146.1,1+4.8$. 137.9. 134.7, 124.9, 124.2, 124.1,84.1,31.9.31.6. 30.2, 29.6, 29.5. 29.4. 29.3. 29.1. 24.8. 22.7. 14.2: MS $\mathrm{m} / \mathrm{z} 432\left(\mathrm{M}^{+}\right)$.

DBT-DtB-DBT (16). To a solution of 2,6-dibromobenzo [1.2-b:4.5-b ${ }^{*}$ dithiophene $11(0.52 \mathrm{~g} .1 .49 \mathrm{mmol})$ and $+(1.41$ g. $3.27 \mathrm{mmol})$ in anhydrous THF $(20 \mathrm{~mL})$ under nitrogen atmosphere were added $\mathrm{Pd}\left(\mathrm{PPh}_{3}\right)_{4}(0.069 \mathrm{~g} .0 .059 \mathrm{mmol})$. Aliquat ${ }^{B} 366(0.34 \mathrm{~mL}, 0.745 \mathrm{mmol})$ and $\mathrm{Na}_{2} \mathrm{CO}_{3}(2 \mathrm{~N} .0 .80 \mathrm{~g}$. $7.45 \mathrm{mmol}$ ) at r.t. The reaction mixture was degassed and stirred at reflux during overnight and then poured into the mixed solution [toluene $(200 \mathrm{~mL})+$ water $(100 \mathrm{~mL})+1 \mathrm{~N} \mathrm{HCl}$ $(20 \mathrm{~mL})]$. The light orange precipitate was filtered off. washed with water $(100 \mathrm{~mL}), 2 \mathrm{~N} \mathrm{HCl}(100 \mathrm{~mL})$, methanol $(100 \mathrm{~mL})$ and then with acetone $(100 \mathrm{~mL})$ to remove starting material as well as the mono-substituted by-product. The resulting precipitate was purified by Soxhlet to give compound $16(0.77 \mathrm{~g} .65 \%)$ as a yellow solid. mp $185^{\circ} \mathrm{C}:{ }^{1} \mathrm{H}$ NMR $\left(\mathrm{CDCl}_{3}\right) \delta 8.67(\mathrm{~s}, 2 \mathrm{H}) .7 .60(\mathrm{~s}, 2 \mathrm{H}) .7 .32(\mathrm{~d}, J=3.6 \mathrm{~Hz}$. $2 \mathrm{H}) .7 .20(\mathrm{~d} . J=3.7 \mathrm{~Hz}, 2 \mathrm{H}) .7 .09(\mathrm{~d} J=3.5 \mathrm{~Hz}, 2 \mathrm{H}) .6 .75(\mathrm{~d}$. $J=3.4 \mathrm{~Hz}, 2 \mathrm{H}), 2.8+(\mathrm{t} . J=7.5 \mathrm{~Hz}, 4 \mathrm{H}) .1 .73(\mathrm{~m}, 4 \mathrm{H}) .1 .38(\mathrm{~m}$. $28 \mathrm{H}), 0.91(\mathrm{t} . J=6.4 \mathrm{~Hz}, 6 \mathrm{H}) ; \mathrm{MS} \mathrm{m} / \mathrm{z} 798\left(\mathrm{M}^{+}\right)$. HRMS(ESI) Calcd for: $\mathrm{C}_{46} \mathrm{H}_{54} \mathrm{~S}_{6}\left(\mathrm{M}^{-}\right): 798.2550$. Found: 798.2546 .

DBT-Anth-DBT (17). To a solution of 2,6-dibromoanthacene $1+(0.50 \mathrm{~g} .1 .49 \mathrm{mmol})$ and $+(1.41 \mathrm{~g} .3 .27 \mathrm{mmol})$ in andydrous toluene $(20 \mathrm{~mL})$ under nitrogen atmosphere were added $\mathrm{Pd}\left(\mathrm{PPh}_{3}\right)_{4}(0.069$ g. $0.059 \mathrm{mmol})$, Aliquat ${ }^{\mathrm{E}} 366(0.34$ $\mathrm{mL}, 0.745 \mathrm{mmol})$ and $\mathrm{Na}_{2} \mathrm{CO}_{3}(2 \mathrm{~N}, 0.80 \mathrm{~g} .7 .45 \mathrm{mmol})$ at r.t. The reaction mixture was degassed and stirred at reflux during overnight and then poured into the mixed solution [toluene $(200 \mathrm{~mL})+$ water $(100 \mathrm{~mL})+1 \mathrm{~N} \mathrm{HCl}(20 \mathrm{~mL})]$. The light orange precipitate was filtered off. washed with water ( 100 $\mathrm{mL}) .2 \mathrm{~N} \mathrm{HCl}(100 \mathrm{~mL})$. methanol $(100 \mathrm{~mL})$ and then with acetone $(100 \mathrm{~mL})$ to remove starting material as well as the mono-substituted by-product. The resulting precipitate was purified by Soxhlet to give compound $17(0.8+\mathrm{g} .72 \%)$ as a yellow solid. mp $347^{\circ} \mathrm{C}: \mathrm{MS} \mathrm{m} / \mathrm{z} 786\left(\mathrm{M}^{-}\right)$. HRMS(ESI) Calcd for: $\mathrm{C}_{510} \mathrm{H}_{58} \mathrm{~S}_{4}(\mathrm{M})$ : 786.3421 . Found: 786.3414 .

DBT-Napth-DBT (18). To a solution of 2,6-dibromonapthalene. $15(0.43 \mathrm{~g} .1 .49 \mathrm{mmol})$ and $4(1.41 \mathrm{~g} .3 .27 \mathrm{mmol})$ in anhlydrous toluene $(20 \mathrm{~mL})$ under nitrogen atmosphere were added $\mathrm{Pd}\left(\mathrm{PPl}_{3}\right)_{4}(0.069$ g. $0.059 \mathrm{mmol})$. Aliquat ${ }^{B} 366$ $(0.34 \mathrm{~mL}, 0.745 \mathrm{mmol})$ and $\mathrm{Na}_{2} \mathrm{CO}_{3}(2 \mathrm{~N}, 0.80 \mathrm{~g} .7 .45 \mathrm{mmol})$ at r.t. The reaction mixture was degassed and stirred at reflux for $12 \mathrm{~h}$ and then poured into the mixed solution [toluene ( 200 $\mathrm{mL})+$ water $(100 \mathrm{~mL})+1 \mathrm{~N} \mathrm{HCl}(20 \mathrm{~mL})]$. The yellow precipitate was filtered off. washed with water $(100 \mathrm{~mL}) .2 \mathrm{~N}$
$\mathrm{HCl}(100 \mathrm{~mL})$, methanol $(100 \mathrm{~mL})$ and then with acetone $(100$ $\mathrm{mL}$ ) to remove starting material as well as the mono-substituted by-product. The resulting precipitate was purified by Soxhlet to give compound $18(0.87 \mathrm{~g} .79 \%)$ as a yellow solid. mp: $302{ }^{\circ} \mathrm{C}:$ MS m/z $736\left(\mathrm{M}^{+}\right)$. HRMS(ESI) Calcd for: $\mathrm{C}_{46} \mathrm{H}_{56} \mathrm{~S}_{4}\left(\mathrm{M}^{+}\right): 736.3265$. Found: 736.3260 .

Aclonowledgments. This work was supported by Brain Korean Program $2 \mathrm{l}$ (BK2L).

\section{References and Notes}

1. Dimitrakopoulos, C. D; Malenfant, P. R. L. Adv. Hater. 2002. 14,99.

2. Facchetti, A; Yoon, M.-H.; Marks, T. I. Adw Ifater. 2005, 17, 1705

3. Barbarella, G.; Melucci, M.; Sotgiu, G. Adw: Mater, 2005, 17, 1581 .

4. Shirota, Y.: Kageyama, Y. Chem Rer, 2007, 107, 953.

5. Murphy, A. R.; Fréchet J. M. J. Chem. Rev 2007, 107, 1066.

6. a) Halik, M.: Klauk, H.: Zschieschang, U.; Schmid, G.: Ponomarenko, S.; Kirchmever, S.; Weber, W. Ad : Hater 2003, 15, 917. b) Choi, H. I.; Cho, D. W., Jin, S. H.; Yoon, U. C. Bull. Korean Chem. Soc. 2007, 28, 1175 .

7. Katz, H. E.; Dodabalapur, A.; Torsi, L.; Elder, D. Chem. Mater. 1995. 7.2238

8. Newman, C. R.; Frisbie, C. D.; da Silva Filho, D. A.; Brédas, J. L.: Ewbank, P. C.: Mann, K. R. Chem. Mater, 2004, 16, 4136.

9. Fácchetti, A.: Mushrush, M.; Kátz, H. E.: Marks, T. T. Adv. Hater: $2003,15,33$.

10. Hong, X. M.: Katz, H. E.; Lovinger, A. J.: Wang, B.-C.; Raghavachari, K. Chent. Moter, 2001, 13, 4686-4691

11. Hotta, S.; Lee, S. A. Swth. Met. 1999, 101, 551

12. Fácchetti, A.: Letizia, I.: Yoon, M.-H.: Murshrush, M.: Katz, H. E: Marks, T. J. Chent Mfoter: 2004, 16, 4715.

13. Ponomarenko, S. A.: Kirchmeyer, S.: Halik, M.: Klauk, H.: Zschieschang, U.; Schunid, G.; Karbach, A.; Drechsler, D.; Alpatova, N. M. Sinth . Met . 2005, 149,231.

14. Ponomarenko, S. A.: Kirchmeyer, S.: Elschner, A.; Alpatova, N. M.; Halik, M.; Klauk, H.; Zschieschang, U.; Schunid, G. Chem. Mater: 2006, 18, 579 .

15. Kim, H. S.: Kim, Y. H.: Kim, T. H.; Noh, Y. Y: Pvo, S. Yi, M. H.: Kim, D. Y.; Kwon, S. K. Chem. Ifater. 2007, 19, 3561.

16. Wang. N. X. Snthetic Commmications. 2003, 33.2119.

17. Beimling, P, Kobmehl, G. J. Chemische Benchte 1986, 119, 3198

18. Lee, S. K.; Yang, W. T.; Choi, J. J.; Kim, C. H.; Teon, S. T.; Cho, B. R. Org. Leth. 2005, 7, 323.

19. Miura, Z:: Chen, H.: Ujii, S.; De Feyter, M.: Zdanowska, P.; Tonkheijm, A. P. H. J.; Schenning, E. W.; Meijer, F. W.; De Schryver, F. C. J.Am. Chem. Soc. 2003, 125, 14968

20. Kaltr, A.; Koch, K.; Gao, W. T. Polvm. Sci. Pol. Phys. 2003, H, 2529

21. Ando, S.; Nishida, T.; Fulijwara, E.: Tada, H.: Inoule, Y.: Tokito, S.; Yamashita, Y. Chem. Water 2005, 17,1261 